\section{FURNITURE DEVELOPMENT TRENDS IN THE ANCIENT ERA OF THE FIRST MANKIND CIVILIZATIONS}

Valeriy Strilets,
https://orcid.org/0000-0002-7669-8770
Senior Lecturer of
the Department of Environment Design,
Kyiv National University
of Culture and Arts,
Kyiv, Ukraine
VStrilets8@gmail.com

Abstract

The aim of the study is to determine the development process of the ancient furniture shaping of the first mankind civilizations (3000 $B C-X I$ century BC). Research methods. The research methodological platform is formed on the basis of a comprehensive systematic functional-structural analysis and is based on identifying trends in the furniture shaping development that can affect the modern furniture design. Therefore, to identify trends in the ancient furniture shaping, methods of systematization by features, localization, and comparative approach were used. The last of the three research methods, the comparative method, provided a comparison of the evolution process features of the furniture shaping phenomena of the ancient period. Scientific novelty consists of identifying development trends in the ancient furniture shaping by its features and in fact confirming its dependence on the influence of both the characteristics of the natural and climatic environment, the anthropometric dimensions of a person, and the worldview and value ideas of that time society. Conclusions. Thanks to

\author{
ПРИНЦИПИ РОЗВИТКУ \\ ФОРМОТВОРЕННЯ МЕБЛІВ \\ У ЕПОХУ ПЕРШИХ ЦИВІЛІЗАЦІЙ \\ людСТВА \\ Валерій Стрілець, \\ https://orcid.org/0000-0002-7669-8770 \\ старший викладач \\ кафедри дизайну середовища, \\ Київський національний університет \\ культури і мистецтв, \\ Київ, Україна \\ VStrilets8@gmail.com
}

\footnotetext{
Мета дослідження - визначення процесу розвитку формотворення меблів у епоху перших цивілізацій людства (3000 р. до н. е. XI cт. до Н. е.). Методи дослідження. Методологічна платформа дослідження формується на основі комплексного системного функціонально-структурного аналізу й ґрунтується на виявленні принципів розвитку формотворення меблів, що можуть впливати на дизайн сучасних меблів. Тому для виявлення принципів формотворення меблів у стародавньому світі використовувалися методи систематизації за ознаками, локалізації та компаративного підходу. Останній із трьох методів дослідження - компаративістський, забезпечував порівняння ознак процесу еволюції формотворчих явищ меблів стародавнього періоду. Наукова новизна полягає у виявленні принципів розвитку формотворення меблів у стародавньому світі за його ознаками та фактичним підтвердженням його залежності від впливу як особливостей природо-кліматичного середовища, антропометричних розмірів людини, так й світогляд-
} 
the research methodological platform, which is formed on the basis of a complex system of functional and structural analysis, a consistent influence on the ancient furniture shaping is recorded besides the environmental, ergonomic, sacral, and also social factors. Identified trends in the formation of ancient furniture models socio-economic, environmental, ergonomic, functional-typological, technical, historical and cultural, aesthetic.

Keywords: genesis, furniture, ancient furniture shaping, functional purpose, furniture culture typology of Mesopotamia and Egypt. но-ціннісних уявлень суспільства того часу. Висновки. У результаті дослідження зафіксовано послідовний вплив на формотворення меблів у стародавньому світі крім екологічного, ергономічного, сакрального, ще й соціального чинника. Виявлені принципи розвитку формотворення стародавніх моделей меблів - соціально-економічні, екологічні, ергономічні, функціонально-типологічні, технічні, історико-культурні, естетичні.

\section{Ключові слова:}

генезис, меблі, меблеве формотворення, функціональне призначення, стародавній світ, типологія меблів культур Межиріччя та Єгипту.

Вступ 10

Метод теоретичного осягнення й осмислення питання формотворення меблів у стародавній період, вочевидь, витікає з площини його генезису. На сьогодні наукові джерела не дають повного розуміння цього явища, особливо такого важливого його сегменту як історично-первісне виникнення формотворення меблів. Нерозуміння причин, ознак іпринципів виникнення, що вже історично реалізувалося протягом тисячоліть в осмислені типологічні форми меблів, і обумовило дослідження цієї локальної проблеми - формотворення меблів у епоху перших цивілізацій. А це, водночас, є науковою проблемою знань історичних витоків меблів як певної об'єктивної закономірності, що обумовила конкретне явище.

До нашого часу дійшли лише образи пишних асирійсько-вавилонських королівських меблів, тоді як під час розкопок були виявлені єгипетські зображення меблів для різних верств суспільства, (Кес, 1981, с. 28).

Мета 2
дослідження

Виходячи з означеної проблеми, мета дослідження полягає у визначенні особливостей походження і розвитку формотворення меблів в історичний період перших цивілізацій людства, або, іншими словами, комплексному виявленні історичних причин і особливостей розвитку формотворення меблів у епоху перших цивілізацій (3000 р. до н. е. - XI ст. до н. е.).

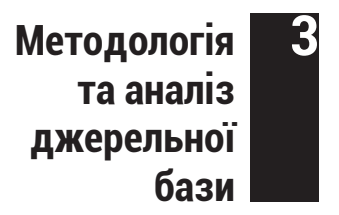

У дослідженні означеної проблеми впроваджено метод комплексного аналізу. Загалом, методологічна платформа дослідження формується на основі комплексного системного функціонально-структурного аналізу й ґрунтується на виявленні принципів розвитку формотворення меблів, що можуть впливати на дизайн сучасних меблів. 
Темою розвитку формотворення меблів у часи перших цивілізацій людства паралельно з дослідженням всієї історії формотворення меблів або інших предметів матеріальної культури того часу займалися такі науковці, як О. Грашин (2007), Д. Кес (1981), В. Любченко (1991), С. Мигаль (1991; 1999), Н. Мухіна (2003), Дж. Чізхолм і Е. Міллард (1999) та інші. Означені автори в основному констатували наявність або описували лише віднайдені археологами меблеві одиниці і їхнє зображення на різних предметах. Безпосередньо в літературі з теми розвитку формотворення меблів, починаючи від перших цивілізацій Шумеру і до Вавилону, а потім і стародавньої цивілізації Єгипту, автор статті не виявив наукової полеміки. Про еволюцію меблів у часи перших цивілізацій світу складно вести дискусії через обмаль фактичного матеріалу (Кес, 1981; Мухіна, 2003). Це спричиняє гіпотетичний підхід науковців у питанні появи та розвитку меблевих форм. Археологія поки що не дає відповіді, як саме відбувався їх розвиток, хоча фіксує появу меблів у IV тисячолітті до н. е. У світових музеях меблі як фактологічний матеріал репрезентують оригінальні зразки-експонати, починаючи з епохи Середньовіччя. I лише поодинокі музеї можуть репрезентувати експонати меблів стародавнього часу, такі як, наприклад, Метрополітен музей у Нью-Йорку США, Каїрський музей у Єгипті, Паризький Лувр у Франції.

На нашу думку, найчіткіше в стислій формі охарактеризував розвиток формотворення меблів цивілізації Межиріччя автор праці «Стилі меблів» Д. Кес (1981). Тому саме його дефініції ми використовуємо найбільше в цій темі.

Окрім того, викладене в статті дослідження є, фактично, продовженням авторської розвідки локальної проблеми - розвитку формотворення меблів у часи перших цивілізацій людства (Стрілець, 2019).

Результати 4
дослідження

Більшість джерел, що вказують на існування меблів у період перших цивілізацій людства, беруть за основу сюжетні малюнки з їхнім зображенням та археологічні музейні експонати: рельєфи (Кес, 1981, с. 28, 45), барельєфи (Кес, 1981, с. 3, 31), статуетки (Кес, 1981, с. 3, 45), кам'яні скульптури (Мигаль, 1999, с. 31; Кес, 1981, с. 33), графічні зображення на картинах (Мигаль, 1999, с. 31; Кес, 1981, с. 38), стінах (фрески) (Мигаль, 1999, с. 31; Кес, 1981, с. 22), вазах (Мигаль, 1999, с. 31; Кес, 1981, с. 45). Залучалися також письмові спогади про меблі задля характеристики народностей (Мигаль, 1999, с. 31; Кес, 1981, с. 30). Винятком із цього ряду є відновлені археологами з фрагментів меблі, віднайдені у гробниці цариці Хетепхерес (Чизхолм \& Миллард, 1999), ціла неушкоджена колекція меблів із поховання фараона 
Тутанхамона в Єгипті (Картер, 1959; Кес, 1981) і деяких зразків із розкопок міста Помпеї в Італії.

Можна припустити, що відколи людина, перейшовши від кочового до осілого способу життя, почала освоювати метали, на межі IV - III тисячоліть до н. е. - бронзу, а в кінці II тисячоліття до н. е. - залізо, - відтоді були створені передумови для вдосконалення інструментарію, методів будівництва житла, а відтак - розвитку формотворення меблів (бронзу знайдено серед решток будівель на палях).

3 розвитком цивілізації, коли спосіб виготовлення меблів дійшов певної логічної послідовності, меблі набули ознак комфорту, зумовлених, насамперед, прагненням до пропорційності з фізичними параметрами людини та їі житла.

Застосування нових, досконаліших матеріалів та розподіл праці у стародавньому світі сприяли швидкому розвитку виробничих сил (Кес, 1981, с. 16).

Загалом, наші відомості про меблі цих цивілізацій дуже обмежені, згідно з ними складно створити картину еволюції меблів, але з наявного наукового матеріалу можна виокремити певні її ознаки.

Так, за морфологічними ознаками декоративно-прикладного мистецтва у цей час у виробництві меблів уже були відомі та застосовувалися такі види-техніки: художній метал, столярне й токарне деревообробництво, лозоплетіння, художня обробка кістки й рогу, художнє ткацтво, можливо, обробка каменю, художня обробка шкіри (згідно з вивченням етнографії сучасних народів, що перебувають на первісній стадії розвитку).

За функціонально-типологічними ознаками найвиразнішим типом меблів указаного періоду є трон - символ як царської, так і божественної влади (є версія первісного поклоніння трону в Трипільській культурі). Він характеризується конструктивно-символічною формою (на троні людина перебуває в сидячому стані, у той час як підлеглі згідно з логікою суспільної ієрархії стоять перед троном).

Уперше з'являються підлокітники, функція яких - забезпечення відпочинку рук, що одночасно підсилює домінантну спрямованість цієї меблевої одиниці на церемоніальну традицію (сидіння на троні - традиція ієрархічності).

За графічними зображеннями меблі цього часу мають певні ознаки комфорту. Наприклад, висока спинка, сидіння з м'якими подушками, підставка для ніг і підлокітники (асирійський трон з Ніневії, перський стілець за зображенням на рельєфі з палацу Дарія в Персеполісі). Підставка для ніг є прямим успадкуванням попередніх досягнень у сфері меблевиробництва, пов'язаних із виникненням меблів як явища (рис. 4.1.). Ця гіпотеза автора статті вказує на вплив повітряного протягу в помешканні 


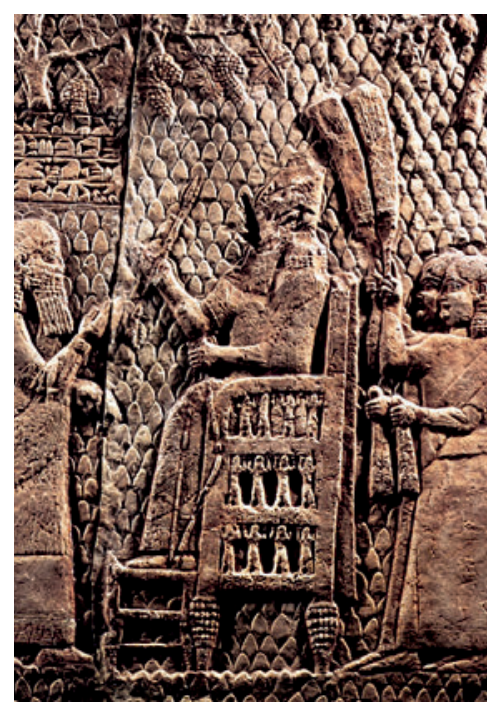

Рис. 4.1. Асирійський трон з Ніневії.

Fig. 4.1. Assyrian throne from Nineveh.

первісного наземного житла людини, в результаті чого вона змушена була піднімати функціональні площини з рівня підлоги до безпечного для ії здоров'я рівня - на 200-700 міліметрів (Стрілець, 2019).

Відомі інші типологічні види меблів періоду Шумеру-Вавилону: ослони-лави, кушетки, табуретки, столи, стільці, ложа, крісла, різні підставки.

Отже, на підставі отриманих даних можна сформулювати характерну ознаку розвитку формотворення меблів стародавніх цивілізацій Межиріччя за соціальними ознаками - вираження у меблевих формах диференціації суспільства.

Відкритим залишається питання соціального обмеження меблів цього періоду, оскільки їх виготовляли нібито лише для середовища монарха, вождя, аристократії, а не для інших верств суспільства (Кес, 1981, с. 30). Археологи в майбутньому повинні підтвердити або спростувати цю гіпотезу.

Крім функціонально-ужиткової інформації, у меблях зберігаються відомості соціальної, магічної, образної орієнтації.

За семантичними композиційно-оздоблювальними ознаками основними носіями широкого спектру інформації $є$ композиційні елементи форми і декору твору - знак, символ, алегорія. Асирійсько-вавилонська орнаментика багата на зображення фантастичних звірів, крилатих биків, левів, птахів тощо. Найхарактернішими асирійськими мотивами були шишки пінії (символ плодючості) - вони використовувалися як опори у тронах, дерево життя (символ походження всього живого), розетки, пальметки, плоди граната. Мали місце й геометричні мотиви, втілені в зірках, зигзагоподібних лініях, колах, хвилястих лініях та симетрично розташованому листі та квітах (Кес, 1981, с. 30). 
Технічні ознаки розвитку формотворення меблів наявні у таких фактах: стійкість меблів у цивілізаціях Межиріччя досягалася за рахунок металевих жорстких кріплень; рубанка тут іще не було, однак за роздільними круглими ніжками меблів можна зробити висновок, що в той час застосовувалася не лише формотворча техніка в меблях для об'ємної пластики деревини, а й існував верстак із металевим пресом, на якому виготовлялися профільовані і круглі металеві деталі (Кес, 1981, с. 30), що вказує на використання техніки карбування в металі.

Металеві інструменти були кращими в застосуванні, основні їхні форми виникли раніше, коли людина користувалася зубилом, свердлом, молотком, сокирою і ножем.

Крім того, активне застосування текстилю в меблях, особливо прозорих тканин для захисту від комах, підтверджує наявність рідкого полотняного переплетення канвових тканин уже в ті часи. На той час теж були відомі шпалери, килими та вишивки (Кес, 1981, с. 30).

За технічними ознаками, як стверджує у своїй праці Д. Кес (1981), виявляються три важливі принципи розвитку формотворення меблів:

- початок виготовлення системних штучних конструкцій меблів на основі шипових з'єднань елементів-деталей;

- запровадження усталеної схеми конструктивної побудови меблів - вертикальних несучих ніжок та горизонтальної рами; блів.

- поява примітивної рамково-тахлевої конструкції ме-

За техніками художнього декорування меблі Вавилону багато прикрашалися металевою фурнітурою, ґудзиками й кільцями з металу; трон був перевантажений золотими й бронзовими прикрасами, набуло значного розвитку мистецтво пластики у металі: вперше згідно з морфологічною класифікацією матеріалів у декорі меблів золото використовувалося у комбінації зі сріблом, бронзою і кісткою. Пророк Амос у своїх описах запевняв, що у вавилонців та асирійців були навіть кушетки із слонової кості. Таке нечуване багатство і в давньому світі було рідкісним явищем (Кес, 1981, с. 30).

3-поміж технік художнього декорування меблів виокремлюються інкрустація та карбування (Павлюк \& Чмелик, 1996).

Зразками скульптурної пластики є зображення грифонів на троні Олександра Македонського (що підіймають його на небо) (Racine, 1888, с. 101, 114); або на одному з тронів вавилонського монарха бічні елементи крісла являли собою вирізані з дерева людські фігурки, які підтримують пана на піднятих руках (Мухіна, 2003, с. 66). 
Нами виявлено такі принципи розвитку формотворення меблів:

1) за історико-культурними ознаками - це різний за мірою вплив суспільної ідеології на декоративне оформлення та формотворення меблів (ієрархічно-принциповий тип);

2) за естетичними ознаками - це розвиток декоративних елементів та художніх видів-технік оздоблення меблів декором (простим чи складним).

У кінці IV тисячоліття до н.е. у Північно-Східній Африці у долині ріки Ніл сформувалася ранньорабовласницька держава Єгипет, якій випала історична доля стати одним із центрів світової культури (Грашин, 2007, с. 23). Характерні риси давньоєгипетського мистецтва, яке було звернене не стільки до світу живих, скільки до царства мертвих, визначила релігія. Витвори мистецтва, згідно з вірою його творців, мали особливу магічну силу й допомагали небіжчику в його загробному житті (Грашин, 2007, с. 23).

Найдавніші зразки меблів віднайдені в похованнях Раннього царства 3 тис. р. до н. е. (уламки скриньок з чорного дерева, інкрустованих слоновою кісткою, звичайний та складальний (х-подібний) дерев'яні табурети з ніжками у вигляді копит жуйних тварин, виконаних із слонових ікл). В епоху Середнього царства (XXI-XVIII ст. до н. е.) досягає свого розквіту столярне мистецтво. Найбільша частина відомих єгипетських меблів створена в епоху Нового царства (XVI-XI ст. до н. е.) (Грашин, 2007, с. 23). При відкритті у 1922 р. гробниці фараона Тутанхамона періоду Нового царства було виявлено багато цілком неушкоджених меблів. Цей факт є одним із небагатьох випадків збереження оригіналів меблів тієї давньої епохи.

За морфологічними характеристиками ДПМ можна констатувати факти наявності у єгипетських меблях таких видів і технік утилітарної галузі прикладного мистецтва, як столярне деревообробництво, видовбування та профілювання, текстиль, фаянс, мозаїка, тиснення шкіри, інкрустація.

Меблі залежно від функціонально-типологічних характеристик поділяються на різні типи (для сидіння, лежання, функціональні площини, ємності тощо). У Єгипті була створена ціла низка типів меблів. Спочатку це були лише низькі лавки і стільці, які вказували, що єгиптяни, як і чимало східних народів, любили сидіти навпочіпки. Привілеєм багатих єгиптян були парадні стільці зі спинкою (Кес, 1981, с. 22), табурети (х-подібні стільці), столи, ложа, стільці (також стільці на зразок шезлонга, із спинкою і довгим, але вузьким сидінням, розрахованим на двох осіб (Мухіна, 2003, с. 55). Скрині мали рамочно-тахлеву конструкцію, випуклу пересувну кришку та великі замки чи двосхилу кришку з тімпаном (Кес, 1981, с. 25). Форми давньоєгипетських меблів логічно 
організовані та зрозумілі. Їх тектоніка враховує властивості матеріалу, однак зовнішній вигляд не завжди відтворює внутрішню суть, тому що єгипетські майстри дотримувалися певного канону. Звідси - певна одноманітність єгипетських меблів, обмежена кількість типів, незмінних упродовж століть форм.

Окрім того, у Єгипті при розкопках були віднайдені предмети меблів для різних верств суспільства (Кес, 1981, с. 28). В них виявляються такі особливості розвитку формотворення:

1) диференціювання суспільства, що спричинило появу нових типів меблевих форм;

2) урахування функціональної типологічної різноманітності у виготовленні меблів;

3) архітектонічне використання світлотіньових ефектів у пластиці зовнішнього формотворення меблів.

Особливу роль у розвитку форм меблів відігравав соціальний чинник.

На творчість меблевих майстрів важливий вплив мала етнічна традиція, підтримувана своєрідною ментальністю, неповторною культурною спадщиною. Тому тут за історико-культурними ознаками виявляємо тенденцію розвитку формотворення меблів, - впливу на технологію виробництва і типологію, - культурного рівня розвитку традицій народів (через національну міфологію, символіку та ремісничу культуру майстрів (матеріал і конструкції меблів)).

Технологія виробництва меблів включає технічні ознаки їхнього формотворення. За формотворчою технікою та галузевим виробництвом меблів найважливішим засобом було столярство. Технічний інструментарій єгиптян для виготовлення меблів відомий нам за збереженими оригіналами, а також за моделями та зображеннями на саркофагах (сокира, пила-ножівка, дворучна пила, тесло, дерев'яний молоток, лучкове свердло, каміння для полірування поверхні (Грашин, 2007, с. 25). Єгипетському столяру бракувало рубанка, токарного обладнання (Мухіна, 2003, с. 47), лещат і верстата (Мухіна, 2003, с. 49).

Для шипів видовбували пази, щоб з'єднати окремі частини дерев'яних виробів. Нерівності на поверхні вирівнювалися пемзою, потім покривались замазкою і фарбувались олійною фарбою; іноді її спочатку обтягували полотном, а потім малювалась орнаментика, ієрогліфічне письмо; малярство покривалося захисним лаком (Мигаль, 1999, с. 26).

Ці дані слугують достатньою підставою для виявлення принципи розвитку формотворення меблів, яка засвідчує використання в ньому досягнень розвитку інструментарію і технологій виготовлення. Тому, на нашу думку, доцільним є введення в дослідження принципів розвитку формотворення меблів аспекту технологічного апарату - технологій. 
3 матеріалів для виробництва меблів (окрім цільної деревини) єгиптяни вже застосовували примітивний спосіб фанерування. Вони облицьовували дешевшу деревину форм меблів пластинами з дорожчих, благородних порід, які, однак, іще не були такими тонкими, як, наприклад, сучасна фанера. У похованні дочки одного з царів III династії був знайдений дерев'яний предмет із шести пластів «фанери», причому кожен пласт був виготовлений з дерева іншої породи: кипарису, алепської сосни, ялівцю, кедра й дерева зизифуса (Мухіна, 2003, с. 50).

За морфологічними ознаками класифікації матеріалів у виготовленні меблів єгиптяни обробляли переважно привозну деревину. Окрім сикомора (дерево всесвіту, що належало богині Нут (Racine, 1888, с. 160)), оливкового дерева, ліванського кедра, тиса та чорного дерева (з верхів'я Нілу та з Аравійського півострова), вони використовували й деревину нільської акації (Кес, 1981, с. 24), тамариск, вербу, ялівець, кипарис, а також волокнисті рослини дельти Нілу (Мухіна, 2003, с. 53).

Меблі на той час у Єгипті мали естетичні композиційнооздоблювальні ознаки. Оздоблення меблів було знаковим (Холмянський, 1992, с. 16). Усі мотиви декору мали символічне значення - захисту фараона чи господаря від ворожих сил (Мухіна, 2003, с. 57). Певний зміст був закладений у тому, що опорам сидінь і лож надавалася форма кінцівок звірів: у давніший час - биків, а пізніше - левів. Для єгиптянина важливим був сам факт наявності такого зображення, що сприймалося як оберіг або талісман (Грашин, 2007, с. 26). По боках спинки здіймалися священні кобри на захист свого володаря, їх крила утворювали ажурні поручні, які обрамляли «картуш фараона» з його ім'ям (Павлюк \& Чмелик, 1996, с. 57-58). Отже, тут первісно виявляється принцип розвитку формотворення меблів - урахування індивідуальних духовних цінностей та потреб замовника.

3-поміж технік художнього декорування меблів застосовувалося різьблення у вигляді ажурних вставок горельєфу, барельєфу (рис. 4.2.) та єгипетського «врізаного» рельєфу і круглого різьблення (священні тварини, сонячний диск, фараон) (Мухіна, 2003, с. 53). На особливо багато оздоблених меблях можна побачити інкрустацію слоновою кісткою, перламутром і навіть золоті накладки (меблі з гробниці Тутанхамона. - рис. 4.3.) (Кес, 1981, с. 24), кольорову емаль, напівкоштовне каміння (рис. 4.2.), кольорові вставки з шматочків синього та білого фаянсу, смальти, срібла (срібло цінувалося більше, ніж золото) (Грашин, 2007, с. 25), скла, каменю. За часів правління XVIII династії фараонів (XIV ст. до н.е.) з'явилася металева фурнітура, що засвідчує високу техніку художньої обробки металу.

Ці дані засвідчують особливості формотворення у епоху перших цивілізацій, які полягають у впровадженні нових 
Деміург: ідеї, технології, перспективи дизайну 2019 Том 2 № 2 Demiurge: ideas, technologies, perspectives of design 2019 Vol. 2 No 2

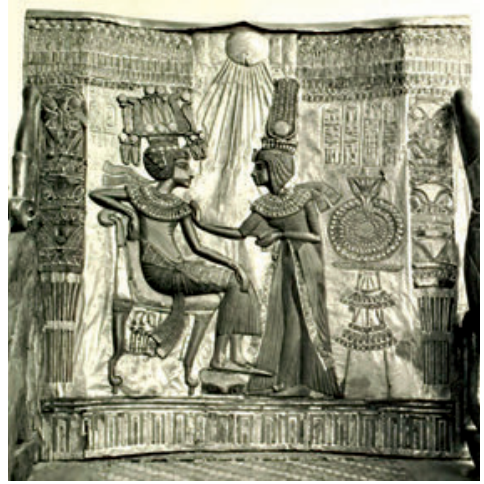

Рис. 4.2. Барельєф на троні Тутанхамона.

$X V I-X I$ ст. до н. е.

Fig. 4.2. Low relief on the throne of Tutankhamun. $\mathrm{XVI-XI}$ ct. BC. is.

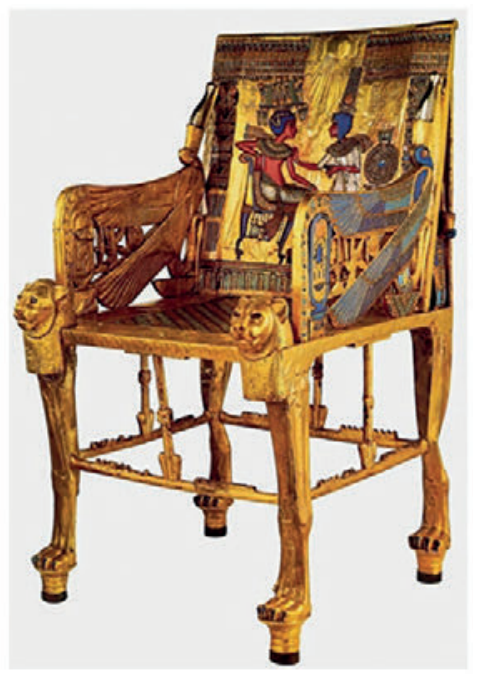

Рис. 4.3. Трон Тутанхамона. XVI-XI ст. до н. е.

Fig. 4.3. The throne of Tutankhamun. XVI-XI ct. BC. is.

різноманітних матеріалів у виготовленні меблів; розвиток формотворчих видів-технік утилітарної галузі декоративного мистецтва; та врахування колористичної гармонії у мистецтві оформлення меблів.

\section{Наукова новизна та практична значимість дослідження
5 Полягає у виявленні принципів розвитку формотворення меблів у епоху перших цивілізацій та фактичному підтверджен- ні його залежності від упливу як особливостей природо-кліма- тичного середовища, антропометричних розмірів людини, так і світоглядно-ціннісних уявлень суспільства того часу.

Висновки 6 Завдяки методологічній платформі дослідження, що формується на основі комплексного системного функціонально-структурного аналізу, крім екологічного, ергономічного, сакрального чинників зафіксовано послідовний вплив на формотворення меблів стародавнього світу ще й чинника соціального. Виявлено принципи розвитку формотворення ста- 
родавніх моделей меблів - соціально-економічні, екологічні, ергономічні, функціонально-типологічні, технічні, історико-культурні, естетичні.

Таким чином, результати дослідження слугують достатньою підставою для об'єктивного виявлення принципів розвитку формотворення меблів. За технічними ознаками можна констатувати послідовний потяг до впровадження нових різноманітних видів матеріалів у виготовленні меблів (для розвою формотворчих та художньо-декоративних технік). За естетичними ознаками - розвиток формотворчих видів-технік утилітарної галузі декоративного мистецтва та врахування колористичної гармонії у мистецтві оформлення меблів.

\section{Список бібліографічних посилань}

Грашин, А.А. (2007). Краткий курс стилевой эволюции мебели. Москва: Архитектура-С.

Картер, Г. (1959). Гробница Тутанхамона (Ф.Л. Мендельсон \& Д.Г. Редер, Пер.). Москва: Восточная литература.

Кацнельсон, И.С. (1976). Культура Древнего Египта. Москва: Наука.

Кес, Д. (1981). Стили мебели. Будапешт: Издательство Академии наук Венгрии.

Любченко, В.Ф. (1991). Меблі стародавнього Єгипту. Львів: Інститут прикладного та декоративного мистецтва.

Мигаль, С., Бугаєнко, Я., \& Любченко, В. (1991). Атрибуція меблів. Львів.

Мигаль, С.П. (1999). Проектування меблів. Львів: Світ.

Мухіна, Н. (2003). Історія меблів. Епохи та стилі. Київ: КНУКІМ.

Павлюк, С., \& Чмелик, Р. (Ред.). (1996). Музей етнографії та художнього промислу Інституту народознавства НАН України: Путівник. Львів: Інститут народознавства НАН України.

Стрілець, В.Ф. (2019). Генеза формотворення меблів. Мистецтвознавчі записки, 35.

Холмянський, Л., \& Щипанов, О. (1992). Дизайн. Київ: Освіта.

Чизхолм, Дж., \& Миллард, Э. (1999). Ранние цивилизации. (А.М. Голова, Пер.). Москва: Росмэн. Racine, A. (1888). I'Ornement polychrome. Paris.

\section{References}

Chisholm, J., \& Millard, A. (1999). Rannie tcivilizatcii [Early civilizations]. (A.M. Golova, Trans.). Moscow: Rosmen [in Russian].

Grashin, A.A. (2007). Kratkii kurs stilevoi evoliutcii mebeli [A short course in the style evolution of furniture]. Moscow: Arkhitektura-S [in Russian].

Carter, G. (1959). Grobnitca Tutankhamona [Tomb of Tutankhamun] (F.L. Mendelson \& D.G. Reder, Trans.). Moscow: Vostochnaia literatura [in Russian].

Katcnelson, I.S. (1976). Kultura Drevnego Egipta [The culture of ancient Egypt]. Moscow: Nauka [in Russian].

Kaesz, G. (1981). Stili mebeli [Styles of furniture]. Budapest: Izdatelstvo Akademii nauk Vengrii [in Russian].

Kholmianskyi, L., \& Shchypanov, O. (1992). Dyzain [Design]. Kyiv: Osvita [in Ukrainian].

Liubchenko, V.F. (1991). Mebli starodavnoho Yehyptu [Furniture of ancient Egypt]. Lviv: Instytut prykladnoho ta dekoratyvnoho mystetstva [in Ukrainian].

Mukhina, N. (2003). Istoriia mebliv. Epokhy ta styli [History of furniture. Ages and styles]. Kyiv: KNUKIM [in Ukrainian]. 
Myhal, S., Buhaienko, Ya., \& Liubchenko, V. (1991). Atrybutsiia mebliv [Attribution of furniture]. Lviv [in Ukrainian].

Myhal, S.P. (1999). Proektuvannia mebliv [Design of furniture]. Lviv: Svit [in Ukrainian]

Pavliuk, S. \& Chmelyk, R. (Eds.). (1996). Muzei etnohrafii ta khudozhnoho promyslu Instytutu narodoznavstva NAN Ukrainy [Museum of Ethnography and Artistic Craft of the Institute of Ethnology of NAS of Ukraine]. Lviv: Instytut narodoznavstva NAN Ukrainy [in Ukrainian].

Racine, A. (1888). l'Ornement polychrome [The polychrome ornament]. Paris [in French].

Strilets, V.F. (2019). Heneza formotvorennia mebliv [The genesis of furniture formation]. Mystetstvoznavchi zapysky, 35 [in Ukrainian]. 